\title{
A DINÂMICA DE POPULAÇÕES MICROBIOLÓGICAS NA ESTABILIZAÇÃO AERÓBIA DE RESÍDUOS ORGÂNICOS DE FECULARIAS DE MANDIOCA (1)
}

No presente trabalho foi estudada a biologia da estabilização aeróbia de resíduos da extração industrial de amido e farinhas, das raizes de «mandioca brava) (Manihot esculenta), planta nativa do Brasil e de grande importância econômica dado seu alto valor nutritivo. Os residuos liquidos dessa extração apresentam elevado teor de matéria orgânica proteica e possuem ácido cianídrico, sendo inconveniente, por essas raxões, seu lançamento aos rios sem prévia estabilização. Essa estabilização tem sido obtida, satisfatòriamente, por intermédio de instalaçōes de valos de oxidação. Os objetivos almejados com o estudo da biologia do sistema eram, principalmente: 1 . Conhecer a composição biologica e a estrutura microscópica dos flocos formados por aeração; 2 . Determinar as causas e, eventualmente, o processo de correção do fenômeno do intumescimento do lôdo («bulking») que freqüientemente ocorre nessas instalações; 3. Determinar a seqüência de populações microbiológicas que se desenvolvem no decorrer do processo de estabilização, de modo a possibilitar o contrôle microscópico da eficiência do sistema de tratamento. Através da aeração do resíduo, em laboratório e comparando os resultados da análise microscópica com os dados que permitiam verificar a evolução do processo de estabilização, foi possivel obter-se os seguintes resultados: 1 . Os flocos são constituídos de uma massa biológica em que predominam fungos filamentosos (Fig. 2). 2. Esses flocos, sendo pouco compactos, originam o fenômeno do intumescimento. 3 . A adição de fósforo ao sistema produz modificação radical na biologia e na estrutura dos flocos, determinando predominância de bactérias, formação de flocos compactos e desaparecimento do fenômeno de intumescimento (Fig. 1; Fig. 2c). 4. Foi estabelecida a seqüência de microrganismos bem como as suas relações de natureza ecológica com as distintas etapas na evolução do processo de estabilização de modo a permitir o reconhecimento microscópico dessas etapas e contrôle do funcionamento e eficiência do sistema (Fig. 3).

\section{N T R O D U C A}

O fabrico de farinhas e extração de amido de raízes da chamada "mandioca brava" ou "mandioca amarga" (Manihot esculenta) outrora, como ainda hoje na maior parte do território nacional, é realizado em pequenas indústrias domésticas, geralmente por processos muito primitivos. Atualmente, entretanto, a sua produção em larga escala, através de um processo realmente industrial vem assumindo importância, com o aparecimento das grandes fecularias (fábricas de fari. nha e de raspa) e amidonarias (indústrias extrativas de amido) no Estado de São Paulo e em alguns outros Estados da Federação. Como conseqüência da concentração da produtividade em áreas restritas, surge o problema da poluição das

Recebido para publicação em 13-10-1967.

(1) Da Disciplina Autônoma de Hidrobiologia da Faculdade de Higiene e Saúde Pública da USP, com subvenção da Fundação de Amparo à Pesquisa do Estado de São Paulo. 
BRANCO, S. M. - A dinâmica de populações microbiológicas na estabilização aeróbia de residuos orgânicos de fecularias de mandioca. Rev. Saúde públ., S. Paulo, 1(2):126-140, dez. 1967.

águas receptoras dos refugos resultantes do processamento da mandioca, detritos êstes particularmente nocivos não só pela Demanda Bioquímica de Oxigênio (DBO) de que são causa, como também pelas elevadas concentrações de ácido cianídrico que os caracterizam. Várias tentativas de tratamento biológico dêsses resíduos resultaram infrutíferas, até que HEss ? (1962) obteve, experimentalmente, a sua estabilização através da aeração prolongada. Esse princípio foi aplicado na prática, pelo mesmo autor, para tratamento de resíduos de indústrias extrativas em várias cidades do Estado de São Paulo, sendo usado, geralmente, o sistema de Valos de Oxidação.

0 estudo pormenorizado, do mecanismo bioquímico da estabilização dos sub-produtos da mandioca merece interêsse especial, entre nós, por duas principais razóes: A primeira, por ser essa uma fonte de amido quase exclusiva e característica de nosso meio. Segundo Hoenne ${ }^{8}$ (1939) a mandioca é originária do Brasil, possivelmente de Minas Gerais ou Bahia, onde podem ser encontradas ainda em estado selvagem, 130 das 160 espécies conhecidas do gênero Manihot. Essas plantas teriam sido cultivadas e selecionadas pelo nativos e, daqui, irradiado, há muitos séculos, para outras áreas tropicais da América do Sul, tendo como limite extremo sul, o Paraguai. A segunda razão relaciona-se com o fato de, como fonte de amido, esta apresentar a peculiaridade de ser extremamente tóxica, o que tráz conseqüências não só para o processo de extração como, principalmente, para o destino a ser dado aos resíduos resultantes do seu processamento. Esses resíduos, contendo ainda ácido cianídrico em concentrações da ordem de $250 \mathrm{mg} / 1^{6}$ podem ser extremamente nocivos aos peixes; por outro lado, se submetidos a tratamento biológico, poderão alterar profundamente o quadro ecológico, determinando, em etapas primárias da estabilização, a seleção de microrganismos resistentes ou até capazes de utilizar o ácido cianídrico como alimento, assunto que será estudado mais pormenorizadamente em trabalhos futuros.

No presente trabalho procuraremos estabelecer a natureza e estrutura microscópica do floco biológico formado por aeração, bem como a sequiência de grupos de microrganismos que se vão sucedendo no meio aeróbio constituído pelo resíduo líquido da extração, aerado mecânicamente, à medida que êsse substrato vai sofrendo as modificações de natureza físico-químicas características da chamada "estabilização bioquímica". Esse estudo qualitativo da dinâmica das populações microbiológicas, a par de revelar situações ecológicas de interêsse teórico, possibilita uma evidente aplicação prática, que é a de permitir o reconhecimento de etapas dessa estabilização, através do quadro microscópico e, dessa maneira, evidenciar, ràpidamente, falhas ou deficiências existentes no sistema.

A bibliografia sôbre dinâmica de populações microbiológicas em sistemas de lôdos ativados é extremamente escassa. Hawkes $^{6}$ (1963) e também McKinney ${ }^{10}$ (1962) resumem os principais dados de que se dispõe a respeito. De acôrdo com êstes, desenvolve-se, no decorrer do processo de estabilização, uma sucessão de microrganismos correspondentes às características de distintos ambientes ecológi$\cos$ que se vão substituíndo no tempo. Bactérias geralmente heterótrofas (com exceção de nitrobactérias) ocupam, geralmente, um nicho físico constituído pelo floco, que é o primeiro e o principal elemento ativo, adsorvente-oxidante, no processo de depuração e que sedimentado em massas, constitui o chamado lôdo biológico ou lôdo ativo. As espécies bacterianas predominantes variam muito, de acôrdo com a natureza do despejo a ser tratado, a ponto de terem os flocos as mesmas características morfológicas e bioquímicas quando se desenvolvem em resíduos contendo compostos orgânicos estruturalmente análogos. Assim, os flocos desenvolvidos em ambiente contendo 
BRANCO, S. M. - A dinâmica de populaçōes microbiológicas na estabilizacão aeróbia de residuos orgânicos de fecularias de mandioca. Rev. Saúde públ., S. Paulo, 1(2):126-140, dez. 1967.

quaisquer tipos de pentoses, são sempre idênticos, porém, distintos dos que se formam em presença de hexoses ENGELBRECHT \& MCKINNEY 4 (1957). Uma vez formados os flocos, êstes serão (ao contrário do líquido antes de flocular) suficientemente ricos em proteínas de molde a permitir um maior desenvolvimento de bactérias proteolíticas que passam a predominar sôbre as não-proteolíticas Allen ${ }^{1}$ (1944). A não existência de suficiente proporção de compostos nitrogenados ou a presença de elevadas concentraçōes de carbohidratos no meio pode resultar na proliferação e predominância de organismos indesejáveis, tais como as bactérias filamentosas do gênero Sphaerotilus e fungos, responsáveis pelo fenômeno conhecido por intumescimento do lôdo ("bulking"), ou seja, formação de um lôdo ativo muito volumoso, de elevado teor de umidade e pequeno pêso específico e que, por êsse motivo, tende a ser levado com o efluente.

Com relação à sucessão de protozoários e microrganismos de maiores dimensões, observa-se também, seqüência idêntica. Neste caso, parece que o principal fator ecológico a determinar a evolução da população refere-se mais à natureza física dos substratos nutritivos que, pròpriamente, à sua composição química. Protozoários saprozoicos - especialmente rizopodos e flagelados - que disputam com as bactérias o alimento existente na forma solúvel, inicialmente predominante no ambiente, dão lugar a uma predominância de sêres holozoicos que se nutrem das próprias bactérias. Entre êstes, desenvolvem-se primeiramente ciliados que se locomovem livremente no meio líquido, os quais, entretanto, sendo muito exigentes quanto ao valor energético do meio, dada sua grande motilidade, entram em declínio, quando as fontes energéticas passam a se tornar escassas. Seu lugar é então ocupado por ciliados sésseis, perítricos. Finalmente, em estágios muito avançados da estabilização, quando o nivel energético do meio cai a valôres relativamente baixos, podem surgir em grandes números, microrganismos de maior talhe, tais como rotíferos e nematoides ou até larvas de insetos como quironomídeos, os quais se alimentam de fragmentos de flocos ou mesmo de protozoários.

Trabalhos recentes têm contribuído para a compreensão de alguns aspectos da dinâmica das populações bacterianas como função da vazão de líquido circulante (Cassell, Sulzer, Lamb III $^{2}, 1966$ ). Com relação à população de protozoários ciliados, trabalhos de CURDS \& VANDYKE ${ }^{3}$ (1966) vieram elucidar vário pontos de importância, referentes à preaominância de diferentes espécies de ciliados em função da existência ou predominância de diferentes espécies bacterianas. Esses autores puderam verificar que bactérias normalmente presentes em sistemas de lôdos ativados, podem exercer distintas açōes fisiológicas quando ingeridas por distintas espécies de protozoários, como única fonte de alimento. Assim, por exemplo, Escherichia coli é tóxica a Paramecium caudatum; "desfavorável" a Vorticella microstoma e a Opercularia coarctata, mas favorece a proliferação de Epistylis plicatilis e Histriculus vorax. Essa "preferência" manifestada pelos ciliados, com relação às espécies bacterianas que ingerem parece comprovar a existência de uma estreita correlação entre a dinâmica das populações bacterianas e os protozoários holozoicos, no processo de estabilização biológica de resíduos.

\section{MATERIAL E METODOS}

No que se refere ao método de obten. ção do resíduo orgânico a ser tratado e ao processo de aeração, a técnica seguida foi, em linhas gerais, a mesma utilizada por Hess ${ }^{7}$ (1962) em seu trabalho pioneiro: pedaços de raiz de "mandioca brava" (Manihot esculenta) foram triturados com água em um liquidificador, deixando-se repousar, durante várias horas, para sedimentação e eliminação do amido. O líquido resultante, de composição idên- 
BRANCO, S. M. - A dinámica de populações microbiológicas na estabilização aeróbia de residuos orgânicos de fecularias de mandioca. Rev. Saúde públ., S. Paulo, 1(2):126-140, dez. 1967.

tica ao resíduo proteico derivado do processamento normal das fecularias de mandioca, era então submetido à aeração com auxílio de um aerador comum, de aquá. rio, após ser inoculado com pequena proporção de lôdo ativo, retirado dos valos de oxidação de uma instalação em funcionamento na cidade de Mogi Mirim, Estado de São Paulo. Esse resíduo líquido é rico em proteínas vegetais ("gluten") e possui aspecto : opalescente devido a uma pequena porcentagem de amido não sedimentável. Na presente experiência, o resíduo em processo de tratamento foi mantido, durarte todo o tempo, em incubadeira de temperatura constante $\left(20^{\circ} \mathrm{C}\right)$. Diàriamente eram retiradas, dessas amostras, alíquotas destinadas à realização dos seguintes ensaios:

1. Volume do lôdo: alíquotas de 100 $\mathrm{ml}$ eram colocadas em provetas graduadas e deixadas em repouso por espaço de meia hora e uma hora, anotando-se o volume de lôdo constituído pelos flocos biológicos formados no processo de estabilização.

2. Teste de estabilidade relativa -0 teste de estabilidade ao azul de metileno (STANDARd Methods for the Examination of Water and Waste Water ${ }^{11}, 1960$ ) era utilizado tendo em vista avaliar empiricamente o grau de estabilização atingido pelo resíduo em fase de aeração. Dada a simplicidade de sua execução e tendo em vista tratar-se sempre de resíduos de idên. tica composição, pareceu-nos ser êsse método, no presente caso, perfeitamente adequado à apreciação da evolução do processo de estabilização, assim como à avaliação do grau de nocividade potencial (relativa à demanda de oxigênio) que o efluente poderia eventualmente causar a um curso dágua que o recebesse.

3. Medidas de $p H$ - foram realizadas, na maior parte das vêzes, por meio de papel indicador "Merck". Algumas determinações foram realizadas, comparativamente, com auxílio de potenciômetro.
4. Aspectos fisicos e organolépticos $O$ odor $\mathrm{e} O$ aspecto ótico foram experimentados diàriamente, do ponto de vista qualitativo.

\section{Exames microscópicos}

a) Exames qualitativos: as amostras eram examinadas diàriamente ao microscópico, com a finalidade de estudar e desenhar a estrutura e composição biológica dos flocos formados, assim como identificar os vários tipos de microrganismos presentes. Além das técnicas de rotina, foi empregada na evidenciação de caracteres morfológicos de protozoários, uma solução de "Separan NP.10" descrita como um polímero sintético de uma amida do ácido acrílico, de elevado pêso molecular, a qual é empregada como auxiliar da floculação no processo de tratamento de águas. Dada a alta viscosidade e transparência dêsse composto, ocorreu-nos utilizá-lo como "freio" à rápida movimentação dos ciliados, possibilitando sua melhor observação. A sua presença no meio revelou-se pràticamente inócua do ponto de vista físiológico, aos ciliados, não produzindo sua morte ou modificaçôes de forma, a não ser para algumas espécies que, após alguns minutos, passaram a encistar-se.

b) Determinaçóes quantitativas: estimativas do número dos vários microrganismos presentes eram obtidas, através de contagens por campo, em uma gôta de volume conhecido, colocada entre lâmina e lamínula. Para densidades muito grandes, foi empregada a sub-divisão do campo, com auxílio de retículos quadriculados adaptados à ocular do microscópio.

\section{RESULT A DOS}

\section{Evolução do processo de estabilização}

Em 8 meses consecutivos de experiências e observações foram obtidos vários ciclos completos, do processo de estabilização, os quais diferem muito pouco entre si, no que diz respeito a suas caracte- 
BRANCO, S. M. - A dinâmica de populações microbiologicas na estabilização aeróbia de residuos orgânicos de fecularias de mandioca. Rev. Saúde públ., S. Paulo, 1(2):126-140, dez. 1967.

rísticas principais. Em linhas gerais, êsses ciclos, do ponto de vista físico e químico, parecem, ainda, idênticos ao que Hess $^{7}$ (1962) descreve sumàriamente, com exceção do fenômeno de intumescimento, que não ocorreu na fase experimental de seu trabalho, provàvelmente em virtude de terem sido empregadas, como inoculum, amostras de lôdo ativo de esta. ções de tratamento de esgotos domésticos, o que provàvelmente enriquecia o meio em nutrientes minerais.

Os principais elementos físico-químicos que nos permitiram avaliar as sucessivas etapas do processo de estabilização foram:

a) Odor: Depois de passadas algumas horas desde a trituração da mandioca para preparo do líquido a ser utilizado na experiência, observa-se com intensidade crescente, um odor cianídrico, em $\mathrm{pH}$ entre 4 e 5 devido, provàvelmente, à hidrólise da amigdalina que é o glicosídio cianogenético presente nas raízes frescas do vegetal. Com o passar dos dias, em processo de aeração, êsse odor é substituído pelo cheiro característico de "leite azêdo", o qual se mantém, via de regra, inalterado, até o $2 .^{\circ}$ ou $3 .^{\circ}$ dia de aeração, coincidindo com um $\mathrm{pH}$ situado em torno de 5,0. Em seguida, êste dá lugar ao odor típico de "môfo", ou intermediário entre môfo e solo molhado, que caracteriza uma rápida elevação do $\mathrm{pH}$ além de outros acontecimentos de natureza química e biológica indicativos de franca estabilização do meio. Algumas vêzes êsse odor se altera ou se associa ao odor típico de maçã e, sempre que a estabilização atinge um grau muito elevado, desprende-se cheiro amoniacal, coincidindo com $\mathrm{pH}$ em torno de 9,0 .

b) $p H$ : Durante os primeiros 2 a 3 dias de aeração, o pH mantem-se em torno de 5,0 para em seguida subir ràpidamente a um valor próximo de 6,5 e, já no $4 .^{\circ}$ dia, atingir valôres situados em redor de 8,0 , que se mantém, com ligeiras oscilações, até que, obtido o grau máximo de estabilização, a citolise bacteriana e conseqüente liberação de matérias nitrogenadas leva à formação de amônia, elevando o $\mathrm{pH}$ a valôres mais altos. Essa última etapa não ocorre, entretanto, quando o meio é re-alimentado periòdicamente com novas cargas orgânicas a serem es. tabilizadas.

c) Aspecto macroscópico: o extrato líquido da mandioca é turvo, opalescente, permanecendo com êsse aspecto, geralmente até o $30^{\circ}$ dia de aeração, quando então se inicia a formação de flocos, os quais sedimentam com maior ou menor rapidez. Os flocos variam de coloração, desde brancos até pardos ou pardo-cinzentos; o líquido sobrenadante mantem-se geralmente amarelado. Os flocos apresentam textura macroscópica frouxa ou compacta, dependendo das condições, como será discutido adiante. No primeiro caso, freqüentemente se vêm flocos pequenos que se mantêm em suspensão, sem sedimentar.

d) Estabilidade relativa: Nos primeiros dias, o azul de metileno se descora no mesmo instante em que é adicionado à amostra. A partir do terceiro dia de aeração, via de regra, observa-se já, uma pequena estabilidade, permanecendo a côr azul por cêrca de 30 minutos. Sòmente na segunda semana de tratamento é que êsse valor se eleva a 24 horas, progredindo, então, ràpidamente, até à estabilida. de ideal de 20 dias, a não ser nos casos em que há intumescimento do lôdo, como será discutido a seguir. Prosseguindo-se com a aeração, e iniciada a fase de autólise celular e degenerescência do floco, a estabilidade tende a decrescer novamente.

e) Volume do lôdo: $\mathrm{Na}$ maior parte de nossas experiências, os sistemas em aeração não foram recarregados periòdicamente com resíduo fresco, pois o nosso objetivo era o de apreciar tôdạ as etapas por que passa o sistema até sua completa estabilização. Assim sendo, a simples medida do volume de lôdo sedimentado em 30 minutos e em uma hora nos pareceu suficiente para avaliar a evolu- 
BRANCO, S. M. - A dinâmica de populaçōes mícrobiológicas na estabilização aeróbia de residuos orgânicos de fecularias de mandioca. Rev. Saúde públ., S. Paulo, 1(2):126-140, dez. 1967.

ção do sistema e a eventual existência de intumescimento sem que houvesse necessidade de medir o índice de Mohlmann, ou índice de lôdo. Constitui êste um dos aspectos mais importantes no processo da estabilização específica dos resíduos de mandioca. Em geral, observa-se já no $3 .^{\circ}$ dia de aeração, a formação de lôdo constituído de flocos biológicos de textura muito frouxa, o qual representa uma proporção de 150 a $200 \mathrm{ml} / 1$, proporção esta que se eleva, no $4 .^{\circ}$ dia, a 400 a $500 \mathrm{ml} / 1$, reduzindo-se, por adensamen. to, a valôres situados em torno de 150 nos dias subseqüentes. A observação microscópica dêsse lôdo revelou ser êle formado, realmente, de flocos de textura muito frouxa, constituído predominantemente de um micélio de fungos filamentosos, com muitos espaços intersticiais, ao contrário dos flocos compactos, constituídos sobretudo de bactérias unicelulares, característicos dos lôdos bem formados. Esse fato levou-nos à suposição de que o meio ecológico, constituído pelo resíduo líquido da mandioca, apresentasse deficiências quanto ao teor de nutrientes in- dispensáveis a um maior desenvolvimento de bactérias, o que favoreceria à proliferação de fungos filamentosos. Considerando a existência de compostos orgânicos suficientes para assegurar o suprimento de carbono, assim como a farta aeração permitindo ambiente permanentemente rico em oxigênio, os elementos faltantes seriam, certamente, micronutrientes minerais, tais como nitrogênio e fósforo sendo provàvelmente êste último o fator limitante, visto ser o resíduo em questão rico em compostos orgânicos nitrogenados (gluten e os próprios cianetos) como já foi mencionado. Foi realizada, então, uma série de experiências, em que se acrescentavam, sais de nitrogênio ou de fósforo ou ambos simultâneamente, que vieram a comprovar, realmente, a deficiência em fósforo, no sistema. Resultados da adição de fósforo, com relação ao volume de lôdo formado, podem ser apreciados nos gráficos típicos constantes da Figura 1. Resultados idênticos foram obtidos ao se adicionar fósforo na proporção de 10 a $15 \mathrm{mg}$ de $\mathrm{P}\left(40\right.$ a $60 \mathrm{mg}$ de $\mathrm{Na}_{2} \mathrm{HPO}_{4}$ ) por litro, em amostras retiradas do pró-

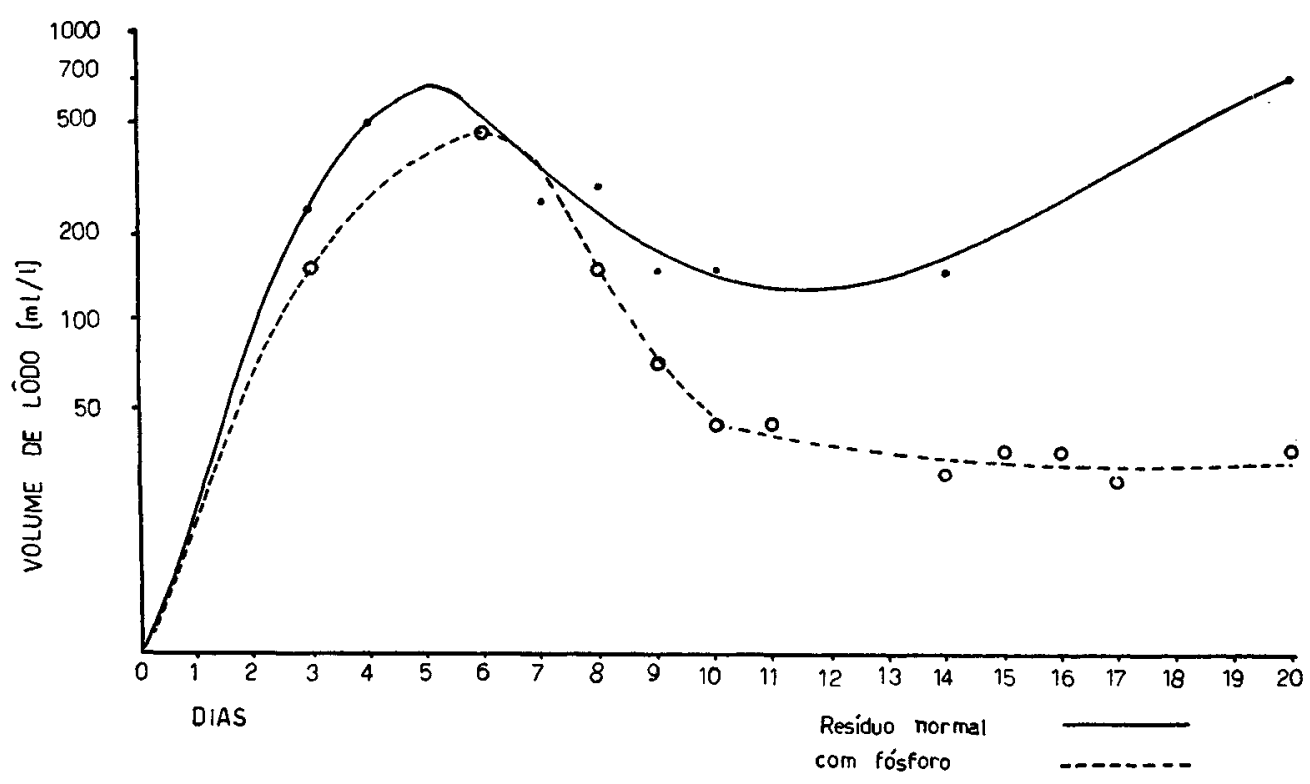

Fig. 1 - Formaçāo de lôdo biológico em amostras aeradas de residuos normais e com adição de fósforo. 
BRANCO, S. M. - A dinâmica de populações microbiológicas na estabilização aeróbia đe residuos orgánicos de fecularias de mandioca. Rev. Saúde públ., S. Paulo, 1(2):126-140, dez. 1967.

prio valo de oxidação de uma dessas instalações industriais, e que apresentava sério problema de intumescimento do lôdo. Essa proporção de fósforo foi baseada na relação DBO : $\mathrm{P}=100: 0,5$ a $100: 0,7$ indicada em IMHOFF ${ }^{8}$ (1966).

\section{Microscopia.}

\section{a) Estrutura dos flocos.}

Via de regra, após 24 horas de aeração, o meio se apresenta ricamente povoado de bactérias, de forma bacilar, que se mantêm isoladamente em suspensão, ou formando pequenos filamentos constituídos de 2 a 3 células. Estimativas grosseiras revelaram números da ordem de 14 milhōes de células por mililitro de amostra. $\mathrm{O} \mathrm{pH}$ do meio mantém-se em torno de 5,0 acompanhado do cheiro característico de leite azêdo. Quando a amostra não é prèviamente mantida em repouso o tempo suficiente, encontram-se grãos de amido, com diâmetro variável entre 7 e 12 micra. Entre 24 e 48 horas, principiam a aparecer leveduras de forma tipicamente elipsoidal apresentando um grande vacúolo além de 1 ou 2 vacúolos esféricos menores, com tamanho de 4,5 a 6 micra, em seu maior eixo. O número dêssas células é da ordem de 1,5 a 3 milhões por ml, em 48 horas, elevando-se a mais de 20 milhões $/ \mathrm{ml}$ nos dias subseqüentes. As primeiras hifas de fungos filamentosos principiam a aparecer, também, com 48 horas de aeração, em número de 2 a 4 mil filamentos por $\mathrm{ml}$, isoladas, em suspensão. Com 72 horas, o número de filamentos se eleva a 15-25 mil por ml, com muitos filamentos ramificados iniciando a formação de micélios muito frouxos que constituem a estrutura fundamental dos futuros flocos. A partir de então, bactérias e células de leveduras principiam a aderir a êsses filamentos, dando origem a flocos com grandes espaços intersticiais, capazes de sedimentar, porém, formando um lôdo muito volumoso. A partir do $5 .^{\circ}$ dia de aera- ção os flocos vão-se tornando mais compactos, com hifas mais estreitamente entrelaçadas e com a adesão de novos elementos, tais como cistos de ciliados, com forma esférica e, mais tarde ciliados sésseis isolados ou coloniais. $\mathrm{Na} \mathrm{Fig.} 2$ está representada, em $a$, a organização geral de um dêsses flocos em formação e em $b$, um floco já bem formado, aos 15 dias de aeração. A partir da formação de flocos, o número de bactérias e de leveduras dispersas passa a reduzir-se ràpidamente atingindo números relativamente pequenos aos 10-15 dias.

Esse tipo de floco, de textura frouxa, com um arcabouço constituído de filamentos de fungos é idêntico ao que en. contramos em amostras colhidas em ins. talaçōes industriais de tratamento de resíduos de mandioca e foi o único tipo que conseguimos obter em laboratório, partindo de aeração dêsses resíduos sem a adição de nutrientes minerais. Ao mesmo tempo, sua presença foi sistemàticamente associada à formação de lôdo intumescido.

A partir de 17 a 20 dias de aeração sem haver recarga orgânica, o floco passa a degenerar. Formam-se, entáo, pequenos flocos que nâo sedimentam, manten. do-se em suspensão. A turbidez da fase líquida aumenta sensivelmente. Parece que a autólise das células participan. tes do floco, a qual é certamente devida à escassez de alimento no meio ricamente oxigenado, leva à liberação de compostos orgânicos solúveis que vão, novamente, enriquecer o meio, constituindo substrato ao desenvolvimento de novas bactérias livres (porém em $\mathrm{pH}$ muito elevado, próximo de 9,0) e de um gran. de número de minúsculos protozoários flagelados. Não há, porém, uma degenerescência total. Amostras que permaneceram no laboratório, por 6 meses, arejadas contìnuamente, exibem ainda seu lôdo intumescido, constituído de flocos que contêm a mesma estrutura filamentosa, no interior dos quais se observam bactérias e cistos de ciliados. Apenas de- 
BRANCO, S. M. - A dinâmica de populaçōes microbiológicas na estabilização aeróbia de resíduos orgánicos de Pecularlas de mandioca. Rev. Saúde públ., S. Paulo, 1(2):126-140, dez. 1967.

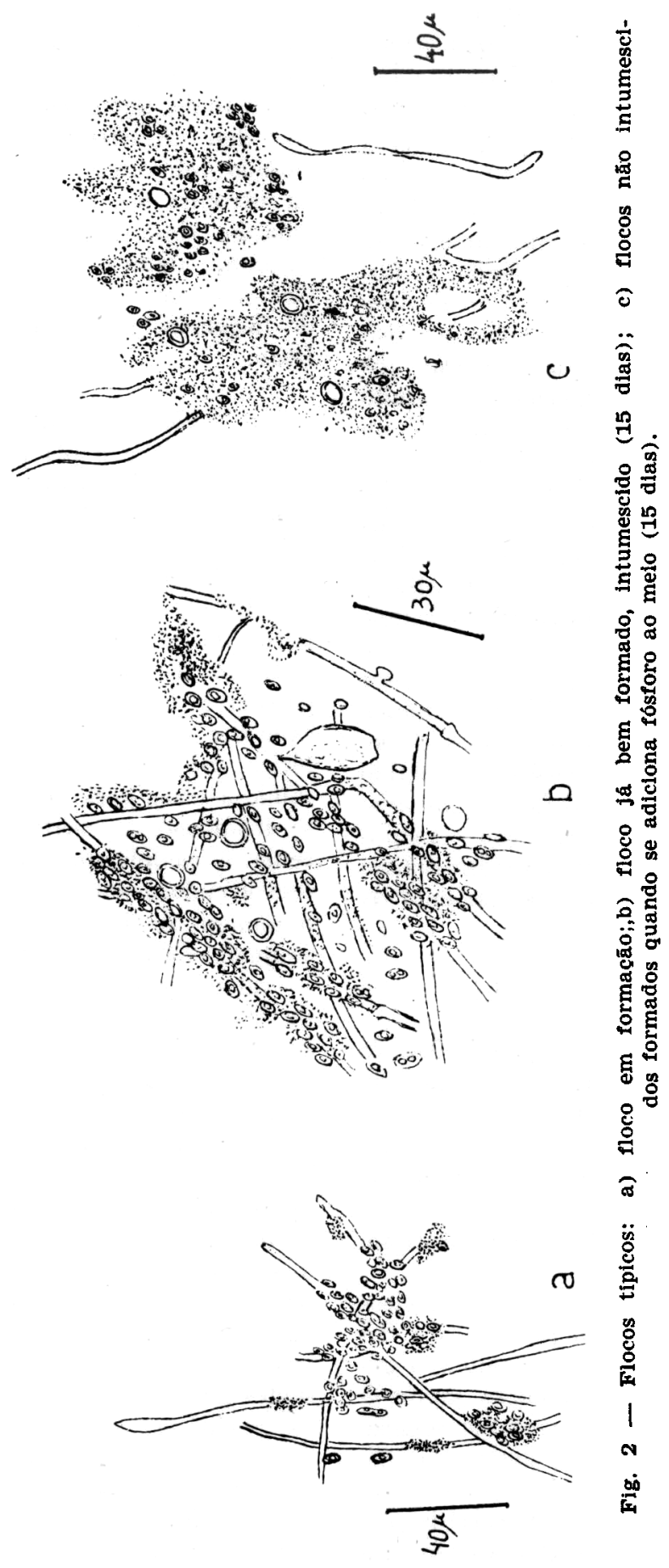


BRANCO, S. M. - A dinâmica de populações microbiológicas na estabilização aeróbia de residuos orgânicos de fecularias de mandioca. Rev. Saúde públ., S. Paulo, 1(2):126-140, dez. 1967.

sapareceram, quase totalmente, os microrganismos independentes do floco e dotados de atividade locomotora, que passaram a ser representados por raros ciliados. $0 \mathrm{pH}$ mantém-se em tôrno de 6,7.

$A$ adição de fósforo ao meio levou a uma evolução sensìvelmente diferente, do floco, em ccrrespondência ao que foi observado em relação ao comportamento do lôdo. Embora se observe, ainda, a formação de grande número de hifas de fungos, as quais constituem o substrato físico do floco, o número de bactérias que se agrega a êsses filamentos é muito maior, preenchendo quase todos os interstícios, formando uma estrutura muito mais compacta. Aos 15 dias de aeração, os tilamentos de fungos pràticamente de. saparecem ou estão totalmente encobertos pelas bactérias (Fig. 2c). Os flocos são muito menores, ocupando, no campo do microscópio, áreas muito menores que os anteriores. Além disso tendem a ser relativamente menores, também, o número de hifas de fungos e de células de leveduras. Fenômeno idêntico foi obtido quando se acrescentou fósforo a amostras retíradas dos valos de oxidação e mantidas em laboratório, com re-cargas diárias de resíduos líquidos do processamento da mandioca.

\section{b) Populações de protozoários}

O desenvolvimento das populações de protozoários, em relação à evolução do processo de estabilização pode ser visualizado através das curvas típicas representadas esquemàticamente na Figura 3. Os seguintes grupos de protozoários caracterizam, distintas fases dêsse processo.

1. Flayelados - Desde os primeiros dias de aeração, surgem protozoários flagelados, entre os quais predomina o gênero Cercobodo, alimentando-se saprozoicamente de matéria orgânica em solução ou mesmo holozoicamente, englobando até mesmo pequenos grãos de amido. Em uma amostra colhida de um valo de oxidação de resíduos de mandioca, foi en- contrado, em abundância, o gênero Tre. pomonas. Os flagelados atingem maior número (cêrca de 500 organismos por $\mathrm{ml}$ ) por volta do $7 .^{\circ}$ dia de aeração, elevando-se, ainda, seu número lentamente até o $15 .^{\circ}$ dia. A partir de então - e coincidindo com uma involução, já descrita, da estrutura dos flocos - surge uma população riquíssima, com números que chegam, algumas vêzes, por volta do $22 .{ }^{\circ}$ dia, até 50.000 organismos por $\mathrm{ml}$, de flagelados muito pequenos, do gênero Bodo.

II. Ciliados - Quando o meio é rico em bactérias, e o $\mathrm{pH}$ principia a elevar-se, inicia-se intensa proliferação de ciliados de locomoção muito rápida, entre os quais predomina o gênero Colpoda, atingindo máxima população por volta do 11. dia de aeração. Entretanto, já a partir do $4 .^{\circ}$ ou $5 .^{\circ}$ dia, coincidindo com o início da floculação, tais organismos passam a transformar-se, em proporções cada vez maiores, em cistos de forma esférica, os quais aderem aos flocos, passando a fazer parte de sua estrutura. Esse fenômeno se verifica em escala cres. cente, à medida que os flocos se vão desenvolvendo e em que, conseqüentemente, o número de bactérias em suspensão as quais constituem seu principal alimento - vai se tornando escasso. Via de regra, do $100^{\circ}$ dia em diante, quando o número de ciliados ativos ultrapassa $40.000 / \mathrm{ml}$, o número de cistos sobrepuja em muito o número de formas ativas, fazendo com que a curva de crescimento dessas passe a declinar ràpidamente. Esse declínio dá lugar ao aparecimento de ciliados sésseis perítricos cujos pedúnculos se prendem á superfície dos flocos, e cujo número passa a elevar-se até atingir a casa dos $1.500 / \mathrm{ml}$, por volta do $15 .^{\circ}$ dia, quando passam, também, a declinar. Nas presentes observações, predominaram, entre os perítricos, os gêneros: Opercularia, Epistylis, Pyxidium e uma forma sem pedúnculo que não pudemos identificar. Finalmente, o declínio dessas formas e também degenerescência dos flocos - 


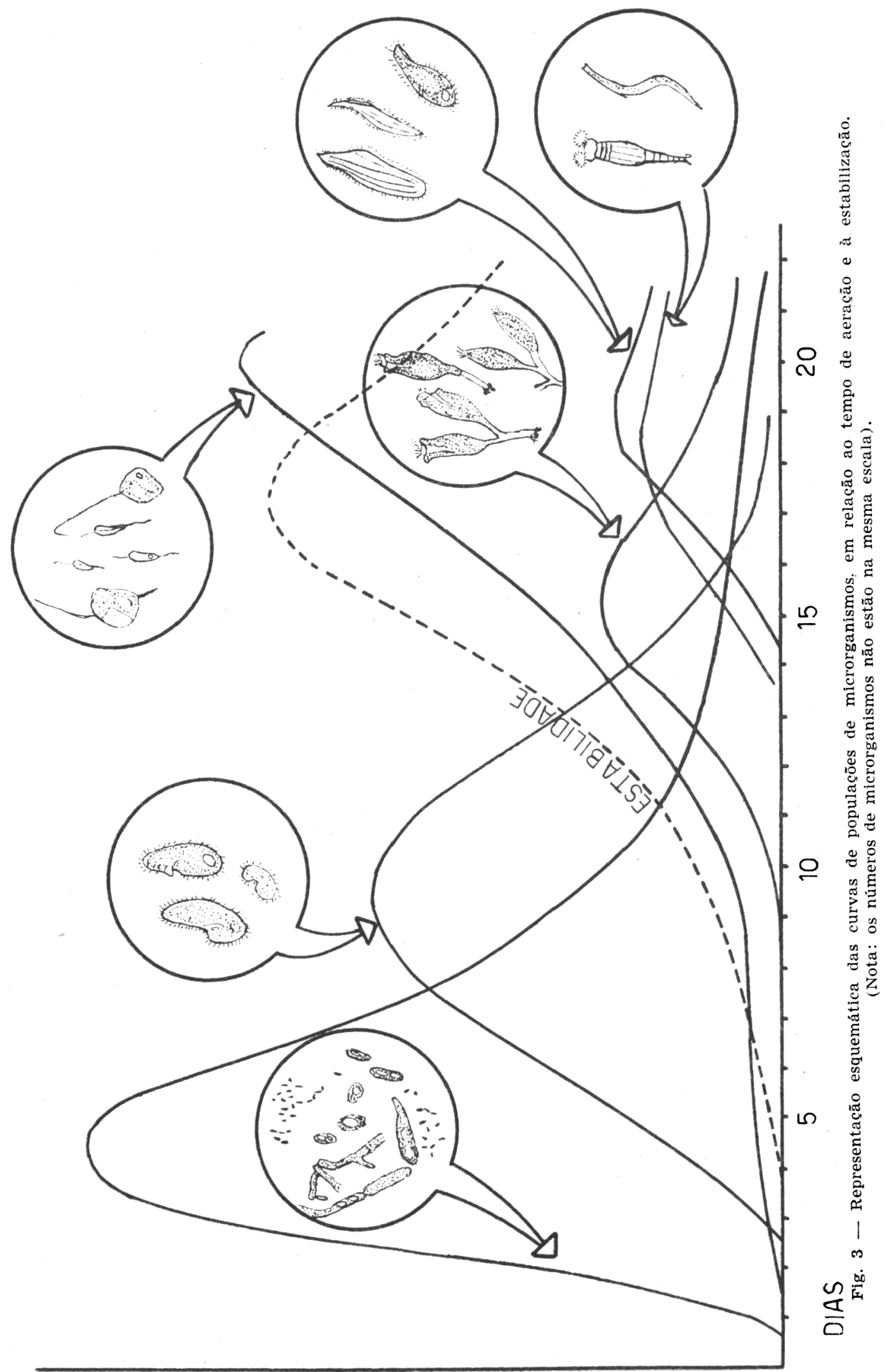

S30j甘7nd Od 
BRANCO, S. M. - A dinâmica de populaçós microbiológicas na establlizacăo aeróbia de resíduos orgânicos de fecularias de mandioca. Rev. Saúde públ., S. Paulo, 1(2):126-140, dez. 1967.

é acompanhada do aparecimento de novas formas de ciliados livre-natantes, porém gymnostomata, de dimensões muito maiores que os anteriores, os quais se alimentam de pedaços dos flocos desfeitos, flagelados, e até mesmo de outros ciliados. Entre êsses ciliados predominam os gêneros Liotus, Amphileptus e Loxodes.

De um modo geral pôde-se observar que a adição de fósforo ao meio não produz uma modificação qualitativa, no quadro da população de protozoários, mas apenas uma antecipação, no tempo, no desenvolvimento de cada uma das formas descritas.

\section{c) Microinvertebrados}

Nematoides de vida livre apareceram, pela primeira vez, a partir do $13 .^{\circ}-14 .^{\circ}$ dia. Entretanto, em experiências ulteriores, em que a amostra a ser aerada era, prèviamente, semeada com lôdo das anteriores, os nematoides passaram a aparecer antes, desenvolvendo-se em maior número (cêrca de $1.000 / \mathrm{ml}$ ). Em uma das experiências feitas com acréscimo de fósforo, surgiram a partir do $5 .^{\circ}$ dia de aeraçáo. Rotíferos do gênero Philodina apareceram, em número muito grande, em uma das experiências de aeração do lí. quido colhido do valo de oxidação, coincidindo seu desenvolvimento com a etapa de grande desenvolvimento dos ciliados perítricos, sésseis.

\section{I S C USAO}

O primeiro fato a chamar a atenção no desenvolvimento da presente experiência é o do intumescimento dos lôdos coincidindo com a presença de grande númèro de fungos nos flocos. Vários autores têm já relacionado o fenômeno do intumescimento com a presença de organismos filamentosos, especialmente bactérias do gênero Sphaerotilus e Finstein \& Heukelekian ${ }^{5}$ (1967), revendo o problema, confirmaram a opinião de que, a predominância de sêres filamentosos não é apenas coincidente, mas constitui real. mente a causa da pequena sedimentabilidade do floco. A predominância de fungos em sistemas de lôdos ativados está geralmente associada à existência de $\mathrm{pH}$ baixo, assim como à presença de concentraçóes elevadas de carbohidratos e à deficiência de alguns nutrientes minerais, entre os quais se destacam o nitrogênio e o fósforo. No presente caso, nota-se que o $\mathrm{pH}$, nos primeiros dias de aeração, é realmente baixo, permitindo o desenvolvimento dêsses tipos de vegetais, em grande abundância. A adição de fósforo ao meio resultou benéfica, do ponto de vista da formação de flocos mais compactos, pesados e ricos em bactérias, embora a diferença sòmente se fizesse sentir em etapas posteriores do processo de estabilização. Deve ser lembrado, entretanto, que na maior parte das experiências descritas, o sistema não era recarregado contìnuamente com novas quantidades de resíduos orgânicos. A recarga sistemática, depois de formados os flocos compactos e, com a permanente adição de fósforo, leva à manutenção do $\mathrm{pH}$ acima de 7 , não permitindo o reaparecimento de fungos, fato que pôde ser verificado quando arejamos, em laboratório, amostras colhidas dos valos de oxidação de uma instalação industrial, com substituição periódica de par. te do líquido por novas quantidades de resíduo fresco às quais adicionávamos fósforo. Nessas condições - que são mais ou menos as condições reais de um sistema de lôdos ativados em funcionamento normal - não ocorrem grandes variações na composição do meio, mantendo-se um equilibrio constante do grau de estabilização e, conseqüentemente, do quadro de populações microbiológicas característico dêsse ambiente ecológico constante. A adição de nitrogênio + fósforo, por outro lado, proporcionou resultados idênticos aos da simples adição de fósforo, o que indica não ser o nitrogênio, no caso, fator limitante, o que era de se prever, uma vez que os resíduos do processamento da mandioca são ricos em nitrogênio orgânico na forma de gluten, ou proteína vegetal. 
BRANCO, S. M. - A dinâmica de populações microbiológicas na estabilização aeróbia de resíduos orgânicos de fecularias de mandioca. Rev. Saúde públ., S. Paulo, 1(2):126-140, dez. 1967.

O fenômeno do intumescimento do lôdo parece, pois, estar ligado a uma causa de natureza estrutural do floco. Realmente, examinados os flocos ao microscópio e comparados aos flocos normais, sem filamentos, observa-se que, enquanto que êsses últimos apresentam um aspecto maciço, em que a maior parte de sua massa é constituída por bactérias intimamente associadas entre si e, freqüentemente inter-ligadas por matriz gelatinosa, como é o caso dos "clássicos" flocos formados por bactérias do gênero Zooglea, os flocos constituídos de fungos são, por outro lado, de aparência muito mais frouxa, apresentando inúmeros espaços formados no entrelaçamento dêsses filamentos, o que lhes comunica a aparência leve de um chumaço de algodão. Tais flocos, embora tenham propriedades adsorventes possìvelmente idênticas às dos demais, ocupam espaço muito grande e, se removidos do meio, apresentam teor de umidade muito maior, isto é, muito menor proporção de matéria sêca. Ademais, pequenas porções dêsses flocos chegam a destacar-se da massa geral de lôdo e, sendo pouco densos, são mantidos em suspensão na fase líquida, fazendo com que esta permaneça com baixo grau de estabilidade relativa. Essa fase líquida, que constitui o efluente de uma instalação normal de lôdos ativados, permanece, assim, com elevada demanda bioquímica de oxigênio, embora a matéria orgânica causadora dessa instabilidade não mais esteja em solução, mas sim floculada e mantida em suspensão.

A sucessão observada, de microrganismos no decorrer do processo de estabilização pode ser indicativa de distintas etapas dessa evolução. Primeiramente em meio ao grande número de bactérias $e$ leveduras em suspensão, existentes desde o início da aeração, inicia-se a proliferação muito rápida de hifas isoladas de fungos, ainda em $\mathrm{pH}$ situado em tôrno de 5. Essas hifas, depois de atingirem certo tamanho, passam a emitir ramificaçōes, dando ensejo à formação de pequenos micélios, constituídos de poucos fila. mentos. Nessa etapa, caracterizada pela presença de grande quantidade de alimento orgânico em forma solúvel, podem proliferar, já, alguns protozoários flagelados capazes de utilizar essa forma de alimento e de viver em ambiente ácido. A formação dos primeiros flocos, pelo entrela. çamento de vários dêsses pequenos micélios e adesão, à superfície dos filamentos, de grande rúmero de bactérias e também células de levedos, coincide com a elevação brusca do $\mathrm{pH}$ do meio. $\mathrm{O}$ início e a rápida proliferação dos ciliados de livre locomoção, que se dá, também, nessa etapa pode ser explicada pelo grande número de bactérias e levedos existentes em suspensão, os quais lhe servem de alimento, em forma de partículas, que è a única forma que pode ser utilizada através do sistema de cílios de apreensão que caracteriza êsses sêres. Seu aparecimento em etapa anterior é dificultado, certamente, pelo $\mathrm{pH}$ muito baixo. Uma única vez em que êsses protozoários apareceram já no $20^{\circ}$ dia de aeração, êsse aparecimento coincidiu com elevação, também anômala do $\mathrm{pH}$, nêsse mesmo período.

$\mathrm{Na}$ medida em que essas bactérias e levedos em suspensão vão desaparecendo do meio e aderindo aos flocos em suspensão, os ciliados livre-locomotores vão assumindo a forma de cistos - que também aderem aos flocos - o que é indicativo do depauperamento do meio líquido, que se vai tornando insuficiente para suportar vida tão ativa e conseqüentemente tão exigente em fontes energéticas. Êsse fato (o da formação crescente de cistos) e o aparecimento imediato de ciliados fixos, pouco ativos e pouco exigentes quanto ao valor nutritivo do meio, é grandemente significativo, em relação à evolução do processo de estabilização, ou seja, a queda progressiva do valor energético do sistema. Em uma instalação de lôdos ativados, em funcionamento normal, a taxa de recargas orgânicas deve ser proporcionada de forma a manter o sistema permanentemente nessa etapa, que é a de máxima produtividade. 
BRANCO, S. M. - A dinâmica de populações microbiológicas na estabilização aeróbia de resíduos orgânicos de fecularias de mandioca. Rev. Saúde públ., S. Paulo, 1(2):126-140, dez. 1967.

O aparecimento dos flagelados livres, de tamanho relativamente grande, indica uma etapa já muito avançada, caracterizada por uma involução, do ponto de vista da estabilização do sistema. A sobrevivência dos flocos, constituídos principalmente de fungos e bactérias, depende, sempre, da existência de certa quantidade de nutrientes orgânicos em forma solúvel, no meio. Submetidos à intensa aeração e portanto, em ativo processo de respiração ou oxidação bioquímica, os microrganismos que o compõem necessitam quantidades proporcionalmente grandes de "combustíveis" a serem oxidados. Quando êstes passam a se tornar escassos no meio $\mathrm{e}$, havendo prosseguimento $\mathrm{da}$ aeração, êsses microrganismos passam a um processo de "autofagia", oxidando suas próprias reservas orgânicas intracelulares. Suas membranas celulares, são, em geral, muito resistentes a essa ação enzimática, sendo as últimas a se destruirem. No momento em que isso acontece, o conteúdo celular, parcialmente digerido, é novamente devolvido ao meio, em forma de compostos orgânicos solúveis, acompanhados de certa concentração de amônia resultante da digestão dos compostos orgânicos nitrogenados. Esses elementos permitem, agora, o desenvolvimento de novas espécies de bactérias e flagelados capazes de viver em ambiente de elevado $\mathrm{pH}$, nutrindo-se de compostos solúveis. Essa degenerescência dos flocos é acompanhada da proliferação de grandes ciliados capazes de ingerirem frag. mentos de flocos, flagelados e até mesmo ciliados menores. Organismos que têm o mesmo significado são também, os rotíferos $\mathrm{e}$, provàvelmente, nematoides.

\section{CONCLUSOES}

As seguintes conclusões resultam do presente estudo:

1. Os resíduos líquidos originados do processamento da mandioca são suficientemente ricos em matéria orgânica nitro- genada, para permitir o desenvolvimento de rica população microbiológica aeróbia, quando submetidos à aeração mecânica, o que leva à possibilidade, demonstrada primeiramente por Hess ${ }^{7}$ (1962), de sua estabilização por êsse processo. A flora que aí se desenvolve, em seus estágios iniciais, é certamente resistente à presença de cianetos, que caracterizam aquêles resíduos, assunto que, entretanto, será reservado para futuras publicações. Entretanto, a deficiência em fósforo, nos resíduos da mandioca, não permite um desenvolvimento bacteriano suficientemente grande para impedir, por concorrência, uma predominância (em volume) de fungos filamentosos, o que dá origem ao fenômeno de intumescimento do lôdo.

2. 0 intumescimento do lôdo está ìntimamente correlacionado com o aspecto físico, microscópico, dos flocos, de textura muito frouxa, formado por microrganismos filamentosos. Tais flocos são muito volumosos, contendo elevada porcentagem de água nos interstícios ou "vazios" que resultam do entrelaçamento das hifas de fungos. A introdução de maior concentração de fósforo no sistema, leva ao aumento da densidade de bactérias no floco, desaparecimento progressivo dos fungos, resultando diretamente disso, a formação de flocos mais compactos e pesados e correção do fenômeno do intumescimento.

3. Observa-se uma seqüência bio-dinâmica caracterizada por quadros microscópicos sucessivos de estrutura e aparência perfeitamente distintas, no decorrer da evolução do processo de estabilização, os quais poderiam ser sumàriamente descritos da seguinte forma: a) bactérias, levedos, hifas isoladas, flagelados, caracterizando uma fase de baixo $\mathrm{pH}$ e abundância de matéria nutritiva solúvel; b) ciliados livre-locomotores, caracterizando clevação progressiva do $\mathrm{pH}$ e grande abun. dância de alimento na forma de partículas diminutas (bactérias e levedos); c) ciliados encistados, formação de flo- 
BRANCO, S. M. - A dinâmica de populações microbiológicas na estabilização aeróbia de resíduos orgânicos de fecularias de mandioca. Rev. Saúde públ., S. Paulo, 1(2):126-140, dez. 1967.

cos, ciliados sésseis, caracterizando ambiente de alta estabilidade, e baixo valor energético; d) flagelados minúsculos, $\mathrm{pH}$ muito elevado, ciliados livre-locomotores muito grandes, rotíferos e nematoides, caracterizando degenerescência dos flocos por autólise das bactérias e outros mi. crorganismos que o compõem, e queda da estabilidade do sistema.

4. Um sistema de lôdos ativados destinado ao tratamento de resíduos dêsse tipo, deveria ser mantido permanentemente no estágio $c$ acima descrito, através da aplicação de recargas orgânicas adequadas e adição de fósforo, a fim de se obter máxima produtividade, evitando, ao mesmo tempo, pêrda de DBO pelo fenômeno do intumescimento do lôdo. $\mathbf{O}$ contrôle microscópico da eficiência do sistema não só é possivel e desejável, como até mesmo demonstrou ser o mais adequado, no presente caso.

\section{S U M M A R Y}

In the present paper, the biology of aerobic stabilization of proteinaceous wastes from starch extraction and manioc meal manufacture from "mandioca bra$\mathrm{va}$ " roots is studied. "Mandioca brava" (Manihot esculenta) is a native plant of great economic importance in Brazil. Wastes from this manufacture have high concentration of organic matter and cyanide and so they are improper to be discharged into rivers without previous stabilization. This stabilization has been achieved successfully through oxidation ditches treatment. The main purposes to be attained with these biological studies were: 1. to know the biological composition and the microstructure of the flocs obtained by aeration; 2 . to determine the causes and eventually the process of correcting the bulking which often appears in these systems; 3 . to know the sequence of microbiologic populations which appear during the stabilization process in order to make possible the use of micros- copy to control effectiveness of the treatment. Aeration of the waste was done in the laboratory and results of the microscopic examination were compared with the data as: $\mathbf{p H}$, odor, amount of sludge and relative stability as indicators of the stabilization process evolution. The following conclusions are attained: 1 . The flocs are formed of a biological mass where filamentous fungi and yeast cells predominate (Fig. 2) ; 2. These flocs are loose and so, responsible for the bulking; 3. Addition of phosphorus to the system produces complete biological modification and changes the microstructure of the flocs. It produces more favorable conditions to bacteria growth and a heavier floc results (Fig. 1, Fig. 2c); 4. The sequence of microscopic organisms as well as their ecological relation with different steps of the process are stablished. So it was possible to recognise those steps by microscopic examination and to control the effectiveness of stabilization (Fig. 3).

\section{REFERENCIAS BIBLIOGRAFICAS}

1. ALLEN, L. A. - The bacteriology of activated sludge, J. Hyg., Camb., 43 : 424-431. Apud HAWKES, H. A. ${ }^{*}$

2. CASSEll, E. A.; SULZER, F. T.; LAMB III, J. C. - Population dynamics and selection in continuous mixed cultures. J. Wat, Pollut. Control Fed., 38 (9) :1398-1409, Sept. 1966.

3. CURDS, C. R. \& VANDYKE, J. M. - The feeding habits and growth rates of some fresh-water ciliates found in activated-sludge plants. J. Oppl. Ecol., $3(1): 127-137$, May 1966.

4. ENGELBRECHT, R. S. \& McKINNEY, R. E. - Activated sludge cultures developed as pure organic compounds. Sewage ind. Wastes, 29(12):13501362, Dec. 1957.

5. FINSTEIN, M. S. \& HEUKELEKIAM, H. - Gross dimensions of activated sludge flocks with reference to bulking. J. Wat. Pollut. Control Fed, 39(1) :33-40, Jan. 1967. 
BRANCO, S. M. - A dinâmica de populações microbiológicas na establlização aeróbia de resíduos orgânicos de fecularias de mandioca. Rev. Saúde públ., S. Paulo, 1(2):126-140, dez. 1967.

6. HAWKES, H. A. - The Ecology of waste water treatment. London, Pergamon Press, 1963.

7. HESS, M. L. - Tratamento de despejos de fecularias de mandioca por oxidação biológica. Revista D.A.E., 23 (46) : 29-35, Set. 1962.

8. HOEHNE, F. C. - Plantas e substâncias vegetais tóxicas e medicinais. Sāo Paulo, Departamento de Botânica do Estado, 1939.
9. IMHOFF, K. Manual de tratamento de águas residuárias. Săo Paulo, Ed. Edgard Blücher Ltda., 1966.

10. McKINNEY, R. E. - Microbiology for Sanitary Engineers. New York, Mc Graw-Hill, 1962.

11 - STANDARD Methods for the Examination of Water and Wastewater. 11th ed. New York, American Public Health Association, 1960. 